\title{
IDENTIFICATION \& SELECTION OF SUITABLE VERMICOMPOSTING SPECIES BASED ON CHEMICAL ANALYSIS OF VERMICOMPOST
}

\author{
Mr.Mohammad Usama ${ }^{1}$, Dr. Monowar Alam Khalid ${ }^{2}$ and Dr.Sumit Raizada ${ }^{3}$
}

Abstract- Vermicompost is formed by decomposition of organic waste by the help of Earthworms and microbes. The advantage of using Vermicompost in soil is that it improves Soil Physical, Chemical and Biological Characteristics. The addition of Vermicompost increases porosity, Water holding capacity. The present papers aims to identify the vermicompost that may better promote or aid plant growth based on the study of analysis of chemical characteristics of vermicompost prepared from Eisenia fetida and Jai Gopal (Perionyx ceylanesis). The findings of this paper showed that vermicompost prepared from Jai Gopal (Perionyx ceylanesis) is found to be better than vermicompost of Eisenia fetida as the soil parameters required for good plant growth are more prominent in vermicompost of Jai Gopal (Perionyx ceylanesis).

Keywords - Vermicompost, Eisenia fetida , Jai Gopal (Perionyx ceylanesis), Chemical Characteristics

\section{INTRODUCTION}

Meeting the food requirements of present generation without compromising with the needs of future generation food requirements and causing harm to our environment is of the most important demand of sustainable agriculture in the present scenario. The adverse impact of agrochemicals on our land, water, food and overall environment has affected us and had reaching alarming level. We have degraded our environment through unsustainable agricultural agricultural practices. So in this situation to avoid further damage to environment and to move towards sustainable agriculture, organic farming through vermicomposting not only provides vital nutrients necessary for plant growth but also helps in maintaining human health by avoid toxic contamination in soil, food grains and water. Vermicomposting or processing of organic wastes into useful manure is carried out by different species of Earthworm. One of the most commonly used species used frequently for vermicomposting is Eisenia fetida. Recently a new variety was developed by Indian veterinary Research Institute,Izzatnagar ,Bareilly known as Jai Gopal (Perionyx ceylanesis) which is developed by mating and selection of Eisenia foetida and Eudrilus eugeneae. The addition of vermicompost in soil improves soil physical, chemical and biological characteristics and help in growth of plants without damaging environment .

\footnotetext{
${ }^{1}$ Department of Environmental Science, Integral University, Lucknow, India

${ }^{2}$ Department of Environmental Science, Integral University, Lucknow, India.

${ }^{3}$ Integral Institute of Agricultural Science and Technology, Integral University, Lucknow, India
} 


\section{STUDY AREA LOCATION AND CLIMATIC CONDITIONS}

Lucknow is the capital of Uttar Pradesh situated on $26^{\circ} 30^{\prime}-27^{\circ} 10^{\prime}$ North latitude and $80^{\circ} 30^{\prime}-81^{\circ} 13^{\prime}$

East longitude, covering an area of $2528 \mathrm{~km}^{2}$.It is surrounded by district Barabanki on Eastern Side , district Unnao on western side, Raebareli on the southern side and Sitapur and Hardoi districts on the northern side. The city is located on the north- western shore of Gomti river Lucknow has a warm humid subtropical climate with maximum temperature in winter around $25^{\circ} \mathrm{C}$ and minimum in the range of 2 to $3{ }^{\circ} \mathrm{C}$. In summers temperatures are very hot and may rise to 40 to $45^{\circ} \mathrm{C}$ range. Lucknow receives an annual rainfall of about 896.2 millimeters from June to September months.

\section{MATERIAL \& METHOD}

Vermicompost Formation:-

Vermicompost pit of size $1.5 \mathrm{~m} \times 2 \mathrm{~m} \times 1.5 \mathrm{~m}$ was prepared for Vermicompost formation. Then the pit was filled with buffalo dung and grass. Buffalo dung and grass was used as composting material. Buffalo dung and grass was mixed in the proportion of 3:1 and is allowed to partially decompose for 15 days. Two different species of Earthworms species Eisenia Fetida and Jaigopal (Perionyx ceylansesis) were used for vermicomposting. 1500-2000 Earthworms were inoculated in each pit. Proper aeration should be maintained in Vermicomposting unit by regular turning the composting material. Optimum Moisture level (30 to $40 \%$ ) is maintained by regular sprinkling of water. Vermicomposting pit is kept in cool, shady place to maintain optimum temperature around 18 to $25^{\circ} \mathrm{c}$ for proper decomposition.
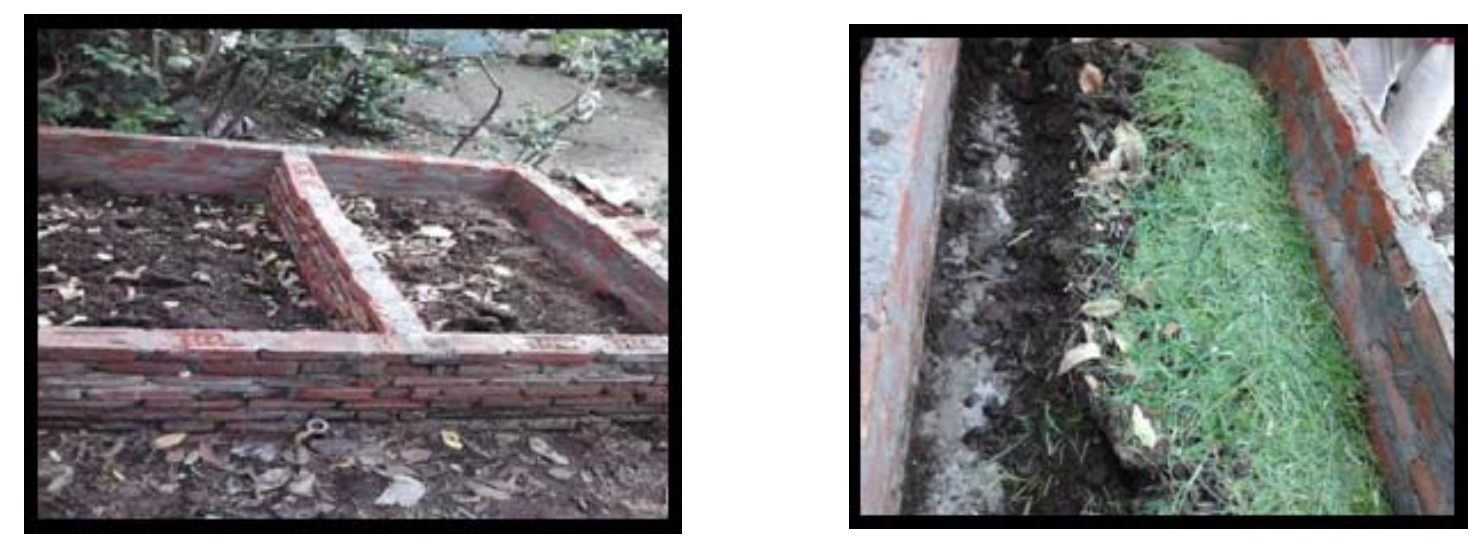

Figure1:- Vermicomposting of wastes by species Eisenia fetida and Jai Gopal” (Perionyx ceylanesis)

Vermicomposting Species:-

Organic wastes are converted into compost by two species Red worms (Eisenia fetida) and Jai Gopal" (Perionyx ceylanesis) 


\begin{tabular}{|l|l|l|}
\hline S.No. & Name of earthworm & Characteristic \\
\hline 1 & Red worms (Eisenia fetida) & $\begin{array}{l}\text { Small, red in colour, tolerates wide range of } \\
\text { environmental conditions, can feed on wide } \\
\text { variety of organic wastes, faster growth and } \\
\text { multiplication. }\end{array}$ \\
\hline 2 & $\begin{array}{l}\text { Jai Gopal" } \\
\text { ceylanesis) }\end{array}$ & $\begin{array}{l}\text { (Perionyxyeveloped through selection and mating plan } \\
\text { which is better than exotic earthworm Eisenia } \\
\text { fetida, Eudrilus eugeneae }\end{array}$ \\
\hline
\end{tabular}

Table 1: Vermicomposting Species \& their Characteristics

\section{RESULT \& DISCUSSION}

\begin{tabular}{|l|l|l|l|l|l|l|l|l|l|l|}
\hline $\begin{array}{l}\text { S. } \\
\text { No. }\end{array}$ & $\begin{array}{l}\text { Name } \\
\text { Vermicomposting } \\
\text { Species }\end{array}$ & OC & pH & EC & $\begin{array}{l}\text { Total } \\
\text { Carbon \% }\end{array}$ & N \% & P \% & K\% & Zn \% & Fe \% \\
\hline 1 & Eisenia fetida & 5.9 & 7.37 & 0.29 & 9.201 & 0.970 & 1.556 & 1.315 & 0.0049 & 0.3208 \\
\hline 2 & $\begin{array}{l}\text { Jaigopal (Perionyx } \\
\text { ceylanesis) }\end{array}$ & 8.7 & 7.40 & 0.33 & 17.559 & 1.072 & 1.626 & 1.659 & 0.0058 & 0.3575 \\
\hline
\end{tabular}

TABLE 2 :- Analysis of Vermicompost

The analysis of vermicompost of two different species of Earthworm indicates that vermicompost of species Jaigopal (Perionyx ceylanesis) is superior in quality in compare to vermicompost prepared from Eisenia fetida as it is having higher percentage of most of the important soil parameters like organic carbon, electrical conductivity, total carbon, Nitrogen, phosphorus, potassium, zinc and Iron. Vermicompost prepared from Jaigopal (Perionyx ceylanesis) is having higher proportion of organic carbon (8.7) in compare to Eisenea fetida (5.9) so they will enhance soil fertility more by improving structure of soil and number of beneficial microorganisms. Physical properties of soil like water holding capacity, infiltration, gaseous exchange and root growth will also be promoted.

Increased presence of Nitrogen (1.072) in Vermicompost will affect carbohydrate and Protein synthesis, photosynthesis, increase in leaf surface (shoot growth), length of growing season, and delays maturity. Vermicompost with higher percentage of phosphorus (1.626) is likely to have early root and shoot development and better formation of seeds and fruit. Increased level of potassium (1.659) will increase photosynthetic activity of leaves, synthesis of amino acids, proteins and sugar, resistance to disease is increased along with increasing plumpness of the grains. Increase presence of zinc (0.0058) will increase growth, seed and bud development, level of chlorophyll. Increase Electrical conductivity (0.33) in vermicompost of species Perionyx ceylanesis indicates that amount of nutrients available for plant growth are available more in Jaigopal (Perionyx ceylanesis). 
Vermicomposting species Jaigopal (Perionyx ceylanesis) is also better than exotic earthworm species Eisenea foetida due to the characteristics like they have high fertility rate, ability to adapt to variable temperature from 20 to $43^{0} \mathrm{C}$ ambient temperature, have a long Life span, hatching to maturity and fast conversion of animal and agricultural waste into superior quality of vermicast. Vermicompost of Perionyx ceylanesis species is very rich in proteins and there is presence of all functional amino acids. So we can say that as Vermicompost prepared from Jaigopal (Perionyx ceylanesis) is having better soil physical and chemical characteristics in comparison to Eisenea foetida and is likely to have better impact on plant growth if we utilized it as a growing medium.

\section{V.CONCLUSIONS}

Vermicomposting of organic wastes by Eisenea fetida and Jaigopal (Perionyx ceylanesis) improves soil physical and chemical characteristics. Out of the two species utilized for processing of organic wastes into useful manure, Jaigopal (Perionyx ceylanesis) is found to have better chemical characteristics so they may enhance soil fertility more and thus promote plant growth. Chemical fertilizers although help in food production but they are harmful for environment in the long run. The advantage of using Vermicompost as a medium for plant growth is that it improves soil fertility without harming environment especially soil. Food production is improved and soil is not degraded, so overall agriculture is sustainable.

\section{REFERENCES}

[1] Alam , M.N., M.S. Jahan, M.K. Ali, M.A. Ashraf and M.K. Islam, 2007. Effect of Vermicompost and Chemical Fertilizers on Growth, Yield and Yield Components of Potato in Barind Soils of Bangladesh. Journal of Applied Sciences Research, 3 (12): 1879-1888.

[2] Atiyeh, R.M., J. Dominguez, S. Sobler and C.A. Edwards, 2000a. Changes in biochemical properties of cow manure during processing by earthworms (Eisenia andrei) and the effects on seedling growth; Pedobiologia, 44: 709-724.

[3] Atiyeh, R.M., S. Subler, C.A. Edwards, G. Bachman, J.D. Metzger and W. Shuster, 2000b. Effects of Vermicomposts and Composts on Plant Growth in Horticultural Container Media and Soil; In Pedobiologia, 44: 579-590.

[4] Atiyeh, R.M., C.A. Lee Edward, N.Q. Arancon and J.D. Metzger, 2002. The influence of humic acids derived from earthworm-processed organic wastes on plant growth; Bioresource. Technology, 84: 7-14.

[5] Azarmi, R., Mousa Torabi Giglou and Rahim Didar Taleshmikail, 2008. Influence of vermicompost on soil chemical and physical properties in tomato (Lycopersicum esculentum) field; African Journal of Biotechnology, 7 (14): 2397-2401. 23

[6] Bansal, S. and K.K. Kapoor, 2000. Vermicomposting of crop residues and cattle dung with Eisenia foetida. J. of Bioresource Technology, 73: 95-98. 30

[7] Barley, K.P., 1959. The Influence of Earthworm on Soil Fertility II: Consumption of Soil and Organic Matter by the Earthworms. Australian Journal of Agricultural Research, 10: 179-185.

[8] Beetz, Alice, 1999. Worms for Composting (Vermicomposting); ATTRA-National Sustainable Agriculture Information Service, Livestock Technical Note, June 1999. 
[9] Bhardwaj, K.K.R. and A.C. Gaur, 1985. Recycling of Organic Wastes; Pub. of Indian Council of Agricultural Research, New Delhi, India, pp: 54-58.

[10] Domínguez, J., 2004. State of the Art and New Perspectives on Vermicomposting Research; In Edwards, C.A., (Ed.). Earthworm Ecology, CRC Press; Boca Raton, FL, USA, pp: 401-424.

[11] Edwards, C.A. and K.E. Fletcher, 1988. Interaction Between Earthworms and Microorganisms in Organic MatterBreakdown. Agriculture Ecosystems and Environment; 24: 235-247. 68

[12] Edwards, C.A. and P.J. Bohlen, 1996. Biology and Ecology of Earthworms (3rd Ed.), Chapman and Hall, London, U.K.

[13] Edwards, C.A., 1998. The Use of Earthworms in the Breakdown and Management of Organic Wastes. In Edwards,

C.A. (Ed.). Earthworm Ecology; CRC Press, Boca Raton, FL, USA, pp: 327-354. 73

[14] Shrikhande, J.G. and A.N. Pathak, 1948. Earthworms and insects in relation to soil fertility. Current Science, 17: 327-328.

[15] Sinha, Rajiv, K., 1998. Embarking on the second green revolution for sustainable agriculture in India: A judicious mix of traditional wisdom and modern knowledge in ecological farming. Journal of Agricultural and Environmental Ethics, Kluwer Acad. Pub., The Netherlands, 10: 183-197.

[16] Sinha, Rajiv K., Sunil Herat, Sunita Agarwal, Ravi Asadi and Emilio Carretero, 2002. Vermiculture Technology for Environmental Management: Study of Action of Earthworms Elsinia fetida, Eudrilus euginae and Perionyx excavatus on Biodegradation of Some Community Wastes in India and Australia. The Environmentalist, U.K., 22 (2): 261-268.

[17] Sinha, Rajiv K. and Gokul Bharambe, 2007. Studies on Agronomic Impacts of Vermicompost Vis-àvis Conventional Compost and Chemical Fertilizers on Corn Crops. CESR Sponsored Project; Griffith University, Brisbane, Australia.

[18] Tomati, V. and E. Galli, 1995. Earthworms, Soil Fertility and Plant Productivity. Acta Zoologica Fennica, 196: 11- 14.

[19] Project report on "Vermicomposting as an Eco-tool in Sustainable Solid Waste Management" by (Asian Institute of Technology - School of Environment, Resources and Development)

1. Dr. C. Visvanathan, Professor, Urban Environmental Engineering and Management Program.

2. Dr. Ing. Josef Tränkler, Associate Professor, Urban Environmental Engineering and Management Program. (Anna University - Centre for Environmental Studies)

[20] http://ivri.nic.in/services/vermi.aspx

[21] http://dcmsme.gov.in/dips/DIP\%20Lucknow.pdf

[22] https://www.agriculturesolutions.com/resources/92-the-why-and-how-to-testing-the-electricalconductivity-of-Soils 
IDENTIFICATION \& SELECTION OF SUITABLE VERMICOMPOSTING SPECIES BASED ON CHEMICAL ANALYSIS OF VERMICOMPOST

[23] Methods Manual ,Soil Testing in India, Department of Agriculture \& Cooperation Ministry of Agriculture Government of India, New Delhi January, 2011 